\title{
Professor Christian Flors selvbiografi
}

\author{
ved Jens Peter Agidius
}

Christian Flor var fra 1830 'rne en af de mest betydningsfulde fødselshjælpere for den vågnende danskhed i Sønderjylland. 1992 er 200-året for hans fødsel. Jens Peter Ægidius - tidligere dansk lektor ved Kiels universitet ligesom Flor - markerer fødselsåret ved at udgive og kommentere Flors hidtil utrykte selvbiografi.

"[1] Jeg er født i Kjøbenhavn d. 1.Jan. 1792; men begge mine Forældre vare fødte i Norge og af agte norsk Oprindelse. Min Fader var Søn af en Gaardejer og Lensmand paa Hedemarken ved Navn Holm, men han fik tidlig til Stiffader en Doctor (Lage) Flor, som, selv uden Børn, sendte min Fader og en Broder til Christiania Latinskole. Disse bleve begge Studenter i Kjøbenhavn. Min Farbroder vendte efter fuldendte Studier tilbage til Norge, hvor han døde som titulær General-Auditør, medens min Fader blev i Kjøbenhavn og studerede Theologi. Skjøndt han hele sit Liv igjennem vedblev med størst Interesse at holde sig til theologisk Læsning, opgav han dog at tage theologisk Embedseksamen af Frygt for, at hans Bryst og Stemme vare for svage til, at han kunde blive en fulddygtig Præst. Han kom da ind i Toldfaget og forskjellige andre Em-//bedsstillinger. Som Regiments-Kvarteermester ved Kronprindsens Regiment giftede han sig med min Moder, en Datter af Kjøbmand Hesselberg i Laurvig. Da hun var 7 Aar gammel, kom hun til Kjøbenhavn og blev der opdragen hos en Onkel og Tante Heegaard.

[2] Jeg kom i v. Westens Skole her i Kjøbenhavn, hvorfra jeg blev Student 1809; et Aar iforvejen var min Fader død af gallopperende Svindsot. Han havde kun efterladt min Moder en meget ubetydelig Formue, og vi vare otte Sødskende, hvoraf tre Sønner. Af disse var min to Aar ældre Broder Secondlieut. i Sø-Etaten (død ugift som Capitainlieutenant nogle og tredive Aar gammel), og min Tvillingbroder var Kontorist $\mathbf{i}$ det Asiatiske Kompagnies Tjeneste (død ugift som Bogholder ved nævnte Komp. og tillige Fuldmægtig i Generaltold- og Commerce-Kollegiet), og altsaa kunde ingen af dem afgive stort til Familiens Underhold. Jeg søgte derfor ved Privatinformation at bidrage, hvad jeg formaaede, hertil; men da jeg, efter i 1810 at have taget Examen philologicum og philosophicum, $i$ et halvt Aar havde deelt min daglige Tid imellem at informere og høre theologiske Forelæsninger, modtog jeg en // 
Huslærerplads hos en Justitsraad Hillerup paa Søbysøgaard i Fyen, for med mere Ro selvstændig at kunne studere Theologi. En indre Trang drev mig imidlertid her til at læse den Tids vigtigste Filosoffer, især Schelling. Efter $2 \frac{1}{2}$ Aars Ophold paa Søbysøgaard vendte jeg tilbage til Kjøbenhavn for atter at optage det afbrudte theol. Studium og, saafremt jeg fandt, at jeg med god Samvittighed kunde paatage mig et kristeligt Præstekald, da at underkaste mig theol. Embedsexamen. Dette gjorde jeg saa efter tre Aars Forløb med bedste Karakter i Oct. 1816.

[3] Fra denne Stund offrede jeg mig ganske til Skole- og Opdragelsesvæsenet. Thi da nu forlænge siden afdøde Prof. M. Nielsen, som dengang var Bestyrer af Borgerdydsskolen i Kjøbenhavn og som i mine to sidste Skoleaar havde været min Lærer i Latin (den eneste virkelig duelige og samvittighedsfulde Lærer jeg havde i al min Skolegang), ønskede, at jeg strax skulde overtage daglig en Deel Timer i hans Skole, hvortil jeg ogsaa selv folte stor Lyst. I denne Stilling tilbragte jeg 5-6, vistnok høist anstrængende, men meget behagelige og lærerige Aar. Thi Professor Nielsen havde megen Godhed for mig, og, hvor for- $/ /$ skjellige vi end af Naturen vare, viste han mig dog bestandig den storste Tillid og Fortrolighed, saa at jeg baade som Lærer i Græsk i de to øverste Klasser og som Larer i forskjellige andre Fag, samt som Skole-Inspektør (jeg havde Bolig og Ophold paa Skolen) fik Lov til at følge min naturlige Lyst til en friere og livligere Underviisning og Skoleopdragelse, naar kun Eleverne i mine Fag til Examen-Artium viste sig fuldkommen hjemme i de der forlangte Kundskaber, hvilket jeg naturligviis sørgede for. Jeg var meget heldig med mine pædagogiske Experimenter og levede i godt Forhold saavel til Skolens Elever som til mine Medlærere, saa at jeg vist aldrig havde forladt Skolemesterveien, dersom ikke et uventet Tilfalde var indtruffet. Tidlig i $1822 \mathrm{blev}$ ved Dødsfald det betydelige Tølløse Præstekald i Holbek Amt ledigt, hvortil Eieren af Tølløsegaard Etatsraad Zeuthen dengang havde Indstillingsret. Denne tilbød det til en Nabopræst, H. Jensen i Soderup, der tidligere havde været Huuslærer $\mathrm{i}$ hans Huus. Men Hr. Jensen, hvis Kald var omtrent ligesaa stort som Tølløse, vilde ikke skifte. I denne Pastor Jensens Huus havde en af mine//Søstre i nogle Aar været Larerinde, og derved var han kommen i personligt Bekjendtskab med hele vor Familie. Han benyttede nu Etatsraad Zeuthens Tilbud til at anbefale mig som en ung Mand, der efter hans Mening vilde kunne tilfredsstille de Ønsker, Etatsraaden nærede med Hensyn til den tilkommende Præst. Dette tilskrev Pastor Jensen mig og bad mig nu betænke, at et saadant Tilfælde næppe oftere vilde møde mig. Efter alvorlig Overveielse og Samtale med Prof. Nielsen fandt vi, at hverken kunde han forsvare at holde paa mig, eller jeg ikke at gjøre et Forsøg paa at naa en saa stor Lykkens Gunst, især da han med største Glæde atter vilde modtage mig, ifald jeg ikke skulde føle mig 
Professor Christian Flor (17921875) som aldre. Fotografi $i$ Dansk Centralbibliotek for Sydslesvig.

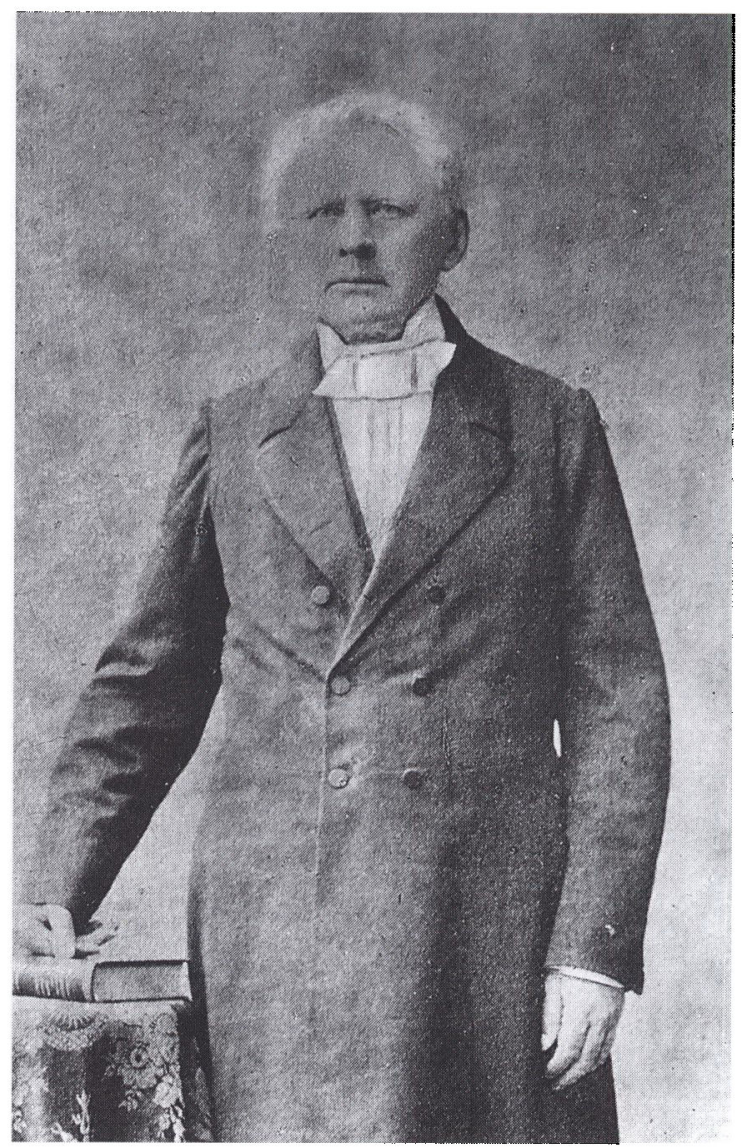

tilfreds i den præstelige Stilling. Og dog havde jeg næppe besluttet mig hertil - saa kjær og lønnende forekom mig min Skolevirksomhed at have været dersom jeg ikke maatte tilstaa for mig selv, at dette Resultat havde jeg kun naaet ved Anstrængelser, som jeg umulig i Tidens Længde vilde kunne fortsætte.

[4] Jeg bestemte da at gjøre den mægtige Tølløse Kirkepatron, som om Vinteren boede i Kjøbenhavn, min Opvartning. Da jeg kun var 30 Aar gammel $/ /$ og ikke mere end $5 \frac{1}{2}$ Aars Candidat, var jeg langt fra at nære noget Haab; men jeg vilde dog gjøre Forsøget af Pligt imod min Moder og mine Søstre. Skjæbnen var mig imidlertid gunstig. Etatsraad Zeuthen var en af Naturen velbegavet og en videnskabelig dannet, samt baade i det praktiske og det selskabelige Liv erfaren, gammel Mand, og hans Væsen og Conversation var livlig og særdeles behagelig. Han maatte saaledes gjøre et overmaade godt 
Indtryk paa mig, og jeg syntes ogsaa at behage ham. Han vilde ingenlunde give mig noget Haab, undtagen for saa vidt han endnu ikke havde givet Nogen Løfte om Kaldet; men jeg maatte i alle Fald bevise, at jeg havde Talegaver (paa hans Spørgsmaal herom havde jeg næmlig svaret, at jeg ikke vidste det, da jeg aldrig havde prædiket, men nu skulde jeg jo holde Dimisprædiken for at kunne indgive Ansøgning, saa kunde han selv høre mig), og jeg maatte skaffe særdeles udmærkede Anbefalinger, især fra Borgerdydsskolens Forstander Nielsen, for at disse kunde veie imod andre Ansøgeres Anciennitet og Værdighed. Jeg fik Tilladelse til at besøge ham oftere, og da han havde været tilstæde i Kirken// ved min Dimisprædiken, for hvilken dHrr. Censorer tilkjendte mig bedste Charakteer, kom han til mig og sagde venligt: »Nu gaaer jeg hjem og sætter Dem øverst paa min Indstilling til Cancelliet.« Kongen udnævnte mig derpaa til Sognepræst for Tølløse- og Aagerup-Menigheder i Holbek Amt.

[5] I Foraaret 1822 kom jeg til Tølløse, og den Godhed, Etatsraad Zeuthen havde fattet for mig, vedblev han paa alle Maader at vise mig til sin Død. Kun $\mathrm{i}$ eet Punkt kom jeg til at krydse hans Planer og tidligere Ønsker. Hans ualmindelig begavede og elskværdige Datter gjorde strax ved første Bekjendtskab et stærkere og alvorligere Indtryk paa mig end jeg hidtil havde følt for Nogen af det andet Kjøn, og med Tiden blev det mig umiskjendeligt, at hun gjengjældte min Tilbøjelighed. Da jeg havde faaet hendes Tilstaaelse, henvendte jeg mig skriftlig til hendes Fader, hvem det vistnok kostede stor Overvindelse, aldeles at opgive sit Ønske og Haab at see sin Datter komme i en ganske anden Stilling, uagtet hun allerede selv havde givet Afslag til forskjellige fornæmme Friere. Han gav imidlertid sit Samtykke, da jeg lovede at skaffe mig Titel og//Værdighed af Doctor, og efter at han først havde beseiret sin egen Forfængelighed, glædede han sig endog ved Tanken om, at han, ved at opføre og indrette en ny Præstebolig, passende for hans Datter og hendes Familie- og Bekjendtskabskreds, kunde paa sine gamle Dage beholde i sin Nærhed sin elskede Datter og sin kjære unge Præst, de To, som nu vare ham mest forpligtede og hvis Selskab igrunden oplivede og opmuntrede ham mest. Men det faldt ikke i vort Lod at kunne i en saadan Stilling vise ham i Gjerning vor Taknemlighed: han døde efter et kort Sygeleie i Slutningen af 1823.

[6] Dette Dødsfald fik en væsenlig Indflydelse paa mit fremtidige Liv. Da min tilkommende Hustrus Arv var bleven omsat til en fast Kapital, og hun meget nødig vilde leve som Præstekone paa samme Sted, hvor hendes Broder var Herremand og Kirkeeier, saae jeg mig om efter en anden Livsstilling. Jeg hørte, at J.L. Heiberg, som dengang var Lector i dansk Sprog og Literatur ved Universitetet i Kiel, tænkte paa at opgive denne Post, og jeg lagde da sidste Haand paa en Afhandling, som jeg havde under Arbejde for den philosophiske 
Doctorgrad: »de vera notione casuum//lingvæ latinæ«, og indsendte den til Kiels Universitet, hvis philosophiske Facultet afgav en særdeles gunstig Dom over dens Indhold og erklærede den fuldkommen værdig til at forskaffe mig den philosophiske Doctorgrad ved Kiels Universitet. Da Heiberg senere hen tog sin Afsked, indgav jeg Ansøgning om at blive hans Eftermand. Jeg fik ogsaa løfte (sic) herom, tog Afsked fra Tølløse Sognekald og blev ansat som Lector i dansk og de andre nordiske Sprog og Literaturer ved Universitetet $i$ Kiel med Titel af Professor, og med det, rigtignok kun mundtlige, Løfte af det Schleswigholstenske Cancellies Præsident, Grev Otto Molkte (sic), at jeg efter et Aars Forløb skulde blive virkelig Professor. Dette Løfte opfyldtes dog aldrig, uagtet min Paamindelse derom, da den egenlig Styrende og Magthavende i Cancelliet, Conferentsraad Hopp efter Forløb af et Aarstid ønskede mig bort fra Kiel og ingenlunde at berede mig der en fastere Stilling.

[7] I Slutningen af 1826 giftede jeg mig og reiste strax derpaa til Kiel. Da vi havde be-//nyttet de første Par Uger til at aflægge Besøg hos adskillige Professorfamilier og deltaget i flere større Selskaber for disse, mærkede jeg, at man ved Universitetet arbeidede nok saa ivrigt og virksomt i Politikens som i Videnskabens Tjeneste. Det blev mig fuldkommen klart, at alle de mest anseete og formaaende Professorer vare mer eller mindre stærkt gjennemtrængte af den slesvigholstenske Doctrin, samt at det tydske Sprogs Udbredelse og Befæstning i hele Slesvig var deres ivrigste Ønske og Bestræbelse, ligesom det var deres bestemte Maal og sikre Haab at faae et Schleswig-Holstein ligeoverfor det danske Kongerige statsretlig realiseret. Thi i vore politiske eller videnskabelige Samtaler ved en Kop The og en Pibe Tobak udtalte de Herrer sig i min Nærværelse temmelig frit og aabent, da de formodede, at jeg villig lod mig oplyse om Forhold, hvilke jeg som tidligere Landsbypræst i Sjælland maatte være uvidende om, og de desuden meget vel vidste, at deres Venner og Forbundsfæller, de tydske Regjeringsmænd i Kjøbenhavn, havde langt mere Magt og Indflydelse end de danske.

[8] Inden jeg bestemte mig til at søge Ansættelse ved Kiels Universitet, havde jeg læst Werlaufs//og Outzens Prisskrifter om det danske Sprogs Skjæbne i Slesvig, og da jeg tillige kjendte mine Landsmænds (selv Videnskabsmænds og Regjeringsmænds i Almindelighed) dybe Uvidenhed om og sørgelige Ligegyldighed for denne Livssag i Danmarks sydligste Deel, kom jeg vistnok til Kiel med den Formodning, at Danskhedens Tilstand i Sønderjylland ikke var bleven bedre, siden disse Skrifter udkom. Men her blev det mig, som sagt, strax aldeles klart, at min Formodning ikke alene var rigtig, men ogsaa, at der existerede et ved Oplysning og Embedsstilling meget stærkt Parti, hvis Hovedbestræbelse gik ud paa Slesvigs fuldstændige Fortydskning. Jeg kunde altsaa ikke nu være i Tvivl om, hvad jeg i min Stilling som Lærer i det danske 
og de nordiske Sprog og Literaturer ved det Universitet, der ligesaa fuldt var Høiskole for Slesvig som for Holsteen og Lauenborg, maatte betragte som mit Maal, hvor vanskeligt, ja usandsynligt dette end maatte synes mig at være. Min første Bestræbelse gik altsaa ud paa at gjøre mig saa nøie som muligt bekjendt med, hvorledes det i Sandhed og i Virkeligheden hang sammen med det danske Sprog i Sønder-//jylland, baade med Hensyn til dets Stilling og Behandling fra Myndighedernes og de Styrendes Side, og hvad Befolkningen, Bønderne og Borgerne, selv følte og tænkte ved Forkuelsen og Forhaanelsen af deres Modersmaal.

[9] Aaret efter rejste jeg til Kjøbenhavn og fik Audiens hos Kong Fredrik d. Sjette. Med megen Deltagelse og Tillid hørte Hs. Majestæt paa min simple og ligefremme Fremstilling af mine Erfaringer og Tanker angaaende denne Sag. Den aldrende Konge havde tidligere gjort de samme Erfaringer og næret de samme Ønsker og disse syntes nu paany at leve op hos ham, saa at jeg forlod ham med Haab om, at jeg kunde blive ham et hjælpsomt Redskab til endnu $i$ hans Levetid at see nogle af disse opfyldte, og at jeg dermed kunde bidrage Mit til at skaffe den miskjendte og undertrykte Danskhed i Sønderjylland nogen Adgang til sin nationale Ret og Ære. Men dette Haab slog aldeles feil. Kong Fredrik d. Sjette var naturligvis med Aarene bleven svagere, medens desværre det tydske Parti baade i Hertugdømmerne og i Kjøbenhavn var med hvert Aar efter Norges Tab blevet//dristigere, aarvaagnere og mægtigere. Da jeg et Aar senere havde Audiens hos Hs. Majestæt og begyndte paa mit gamle Thema, afbrød han mig med de Ord: "Ja, min kjære Flor, lad os aldrig tale om de Ting«, og begyndte at spørge mig om, hvor jeg boede, og andet deslige. Formodentlig har han prøvet paa at minde Otto Molkte eller Hopp om Sprogsagen i Slesvig; men denne sidste, som var baade dristig og snu, og havde al Magten i det slesvigholsten-lauenborgske Cancelli, har forstaaet at møde Spørgsmaal i dette Anliggende, enten de kom fra Kongen eller Cancellipræsidenten, paa en saadan Maade, at de tabte Lysten til at gjentage dem.

[10] Jeg maatte saaledes opgive Tanken om at have en mægtig Støtte for mine Ønsker og Bestræbelser i Hs. Maj. Kongen; thi jeg indsaae, at enhver saadan Fremstilling af Danskhedens Tilstand i Slesvig kun maatte pine hans ædle og folkefølende Hjerte, uden at det kunde gjengive ham den Kraft og Fasthed, som Alderen havde berøvet ham. Og hvor jeg søgte hen hos de høiere Regjeringsmænd eller i Kongens Om-//givelser, fandt jeg ingen Sympathi for mit Ønske om at frelse den endnu levende Danskhed i Slesvig, undtagen hos den bekjendte Oberstlieutenant Kammerherre Abrahamson, (som erklærede mig, at han selv i flere Aar havde arbeidet til dette Maal, men tilsidst havde opgivet alt Haab om at naae det. Han lovede imidlertid at staae mig bi, hvis nogen Leilighed hertil tilbød sig, og han holdt Ord). Der stod mig da ingen 
anden Vei aaben, end at forsøge, om Slesvigernes seige naturlige Vedhængen ved deres danske Sprog, som de iøvrigt knap kendte uden som et fattigt og foragtet Almuesprog, kunde vækkes og oplives til en varm Kjærlighed til det gamle Modersmaal, som Skaberen havde anvist dem til aandelig Arv og Eie, og om der dermed for dem kunde vækkes Syn for, at det var deres stolte Ret og deres hellige Pligt at bevare og forsvare dette som deres bedste menneskelige Eiendom. Med andre Ord: jeg maatte forsøge, om ikke den aandelige og moralske Kraft, som jeg saae i en sygelig Tilstand hos den slesvigske//Befolkning, men hvoraf jeg troede nu og da at have bemærket stærke Glimt og kjendelige Prøver, kunde ved Oplysning vækkes til fornyet Liv.

[11] At giøre dette Forsøg, saavidt jeg forstod og formaaede, blev da nu mit Livs Opgave, og fra denne udgaaer i Grunden Alt, hvad jeg senere som virksom Statsborger har foretaget mig. Jeg havde ønsket og haabet at kunne blive et trofast, nyttigt og kjærkomment Redskab for den danske Konge og Regjering til at bøde paa den Uret og de Ulykker, som tidligere Regjeringers Feil havde voldet det gamle Sønderjylland; men i dets Sted fik jeg Udseende af en urolig og besværlig Opponent imod min Konge og Regjering, fordi mit Liv nu maatte blive en stadig Kamp med den Embedsstand, som danske Konger og Regjeringer selv betroede Landets Styrelse til. Dette maatte jeg imidlertid indtil 1848 finde mig i, saafremt jeg vilde blive min Samvittighed og min Overbeviisning tro. Og jeg kunde dette saa meget bedre, som jeg ikke stod ene med denne Overbeviisning; thi den deltes fuldstændig og// fulgtes saavel i Bekjendelse som i Handling af mine boglærde og sønderjydske Venner, begge af aldgammel slesvigsk Folkerod: Afdøde Etatsraad C.Paulsen, født i Flensborg, som var et halvt Aar tidligere end jeg ansat som Professor i den slesvigske Ret, og afdøde Justitsraad Jaspersen, født i Treia, Justitiarius (Birkedommer) i Gelting i Angel.

[12] Mine Bestræbelser for at vække aandeligt Liv og Bevidsthed hos den danske Befolkning i Sønderjylland bleve ikke uden Frugter; men det vilde her blive for vidtløftigt at beskrive min forskjellige og mangeartede Virksomhed i denne Henseende. Jeg skal derfor indskrænke mig til at næune de vigtigste almindelige Midler, jeg fik istand og kunde benytte for at naae mit Maal. Jeg udgav først »Lehrbuch der dänischen Sprache«, dernæst »Dansk Læsebog eller Haandbog i den danske Literatur « og siden »Anleitung zum Übersetzen aus dem Deutschen ins Dänische«. Det lykkedes mig at faae et dansk Blad kaldt tillive i Haderslev, "Dannevirke«, udgivet af en Borger, Pet.Chr.Koch, født i Gram Sogn; senere et lignende i Aabenraa, »Freia«, udgivet// af Uhrmager Fr. Fischer, født dersteds; og et dansksindet Blad i Flensborg: »Flensburger Zeitung«, hvis væsenligste Medarbeider og senere selvstændig Redaktør var Dr. C. Manicus, født i Angel. Fremdeles fik jeg oprettet Rødding Folkehøiskole 1844. 
[13] Jeg bør tilføie, at med Hensyn til min Stilling som Lærer ved Universitetet i Kiel befandt jeg mig altid i et meget godt Forhold til Studenterne, og jeg havde i mange Aar forholdsviis ikke faa Tilhørere ved mine Forelæsninger over det danske Sprog og de danske Hovedforfattere, Øhlenschlæger og Holberg, ja endog over Svensk og Islandsk. Men tilsidst naaede den slesvigholstenske Doctrin en saadan Udbredelse og den antidanske Stemning en saadan Styrke i Kiel, at ingen Student mere vilde eller turde høre mine Forelæsninger. I det private Liv stod jeg ogsaa bestandig paa en meget smuk og venskabelig Fod, saavel med Professorerne som med Stadens andre Beboere, indtil efterhaanden den selskabelige Omgang af sig// selv mer og mer maatte ophøre. Jeg søgte derfor og fik min Afsked 1845, og har siden den Tid levet som Privatmand, dels i Slesvig, dels i Kongeriget, dels $2 \frac{1}{2}$ Aar i Udlandet. I 1848 og 49 var jeg Medlem af den constituerende Rigsforsamling i Kjøbenhavn; i 1849-50 havde jeg, navnlig paa Finansministeren Grev Sponnecks Opfordring og under hans Ressort, en Tillidsstilling i Flensborg; fra 1855 til 1863 var jeg Medlem af Rigsraadet, valgt af den slesvigske Stænderforsamling. I 1849 [rettelig: 1848] bleve jeg af Hs. Maj. Fredrik d. Syvende udnæunt til virkelig Etatsraad, 1850 til Ridder af Dannebrog og 1859 [rettelig 1854] til Dannebrogsmand.«

\section{Efterskrift}

Manuskriptet, hvorefter Christian Flors selvbiografi her er trykt, findes blandt Flors papirer i Det kongelige Bibliotek, NkS 1766 fol.III, indskrevet i en lille bog i kvartformat med sort stift papbind. Det omfatter foruden titelbladet med teksten "Christian Flor « skrevet stort i latinsk skriveskrift og derunder en tilføjelse i blyant af en senere hånd: "skrevet af Pet. Chr.Koch efter Flors Diktat«, 18 siders håndskreven tekst i gotisk skriveskrift. Derefter følger på den 19de side et følgebrev til det kongelige danske Ordenskapitel, skrevet utvivlsomt egenhændigt af Flor. Resten af bogens i alt 30 sider står tomme. Indlagt $\mathrm{i}$ samme bog findes desuden en skrivelse fra Ordenskapitlet stilet til »Høivelbaarne Herr Etatsraad Flor, Ridder af Dannebrogen«, indeholdende en opfordring til at efterkomme en tidligere fremsendt anmodning om wat meddele Ordenscapitulet en Optegnelse af Deres Levnetsløbs vigtigste Begivenheder, til Brug for Ordenernes Historiske Samling«. Skrivelsen er en for-skrevet formular i formfuldendt, upersonlig gotisk håndskrift, udfyldt til lejligheden med titel, dato (31. Mai 1866) og underskrifter af Ordenskapitlets vicekansler, L.N. von Scheele og dets sekretær J.P.Aastrup.

Ud fra dette foreliggende materiale, tillige med en indførsel i Ordenskapitlets protokol, kan følgende forløb rekonstrueres: i 1850, med udnævnelsen til ridder 
af Dannebrog, må Flor have fået den første opfordring fra Ordenskapitlet til at indsende sin levnedsbeskrivelse; da den ikke blev efterkommet, har det over femten år senere sendt en rykker. Også den fik lov til at ligge en rum tid: hele sommeren 1866, indtil Flor i slutningen af oktober vendte hjem til sin enkemandsbolig i København efter at have tilbragt mindst fem måneder hos sin søn i Sverige, uden åbenbart at have efterladt besked om, hvorhen ankommen post kunne eftersendes. Det siger i sig selv en del om, hvor vel han nu kunne undvære verden, og også regnede med, at verden kunne undvære ham. Deraf kan man så videre slutte, at den levnedsbeskrivelse, han nu omsider, i efteråret 1866, besluttede at få nedskrevet, er et tilbageblik på en i alt væsentligt afsluttet livsgerning. Flor nærmede sig $\sin 75$ års dag - som også blev passeret, inden han fik arbejdet afsluttet og afsendt.

Nedskriften må være sket $i$ ugerne omkring eller lige efter denne fødselsdag. Samtidig med at han har gået og overvejet indhold og udformning, må han have besindet sig på, at hans hånd, som i sin tid havde skrevet ikke så lidt, ikke mindst utallige breve, nu på hans ældre dage var blevet noget usikker og rystende - følgebrevet tillader os en sådan bedømmelse - så han ikke kunne byde Ordenskapitlet det; i hvert fald har han åbenbart anmodet sin gamle ven og »krigskammerat«, tidligere redaktør af bladet »Dannevirke« i Haderslev, Peter Christian Koch, der siden 1856 havde boet i København og nu ernærede sig som fotograf, om at nedskrive efter sit diktat. Koch havde en fast og klar håndskrift; han havde endda holdt foredrag i Sønderjydsk Samfund om "skønskrivning, hurtigskrivning og retskrivning « ${ }^{1} \mathrm{i}$ årene efter at han var flyttet til København. I den sammenhæng ser det i øvrigt også ud, som om hans håndskrift er undergået en vis ændring, idet den her ikke er umiddelbart genkendelig i forhold til skriften i Kochs breve til Flor; de yngste af disse i Flors arkiv er fra $1855 .^{2}$ Til formålet har Flor anskaffet den lille bog med de 30 blade, og heri har så Koch nedskrevet manuskriptet, formentlig i flere omgange, og endnu her i 1867 altså i gotisk skrift.

I første omgang, ser det ud til, har Flor godtaget denne nedskrift og gjort den klar til afsendelse, idet han efter den har tilføjet sit følgebrev, som over for Ordenskapitlet undskylder og forklarer den skete forsinkelse. Brevet er også underskrevet, og dateret »Kjøbenhavn 23 Januar 1867«. Eller også er det hele, både selvbiografi og følgebrev, at opfatte som en kladde.

I hvert fald er den lille sorte bog ikke blevet sendt til Ordenskapitlet, men må være forblevet blandt Flors private papirer for så ved ordningen af boet efter hans død i 1875 at være gået sammen med disse til Det kongelige Bibliotek.

Karakter af kladde har manuskriptet derved, at det er gennemrettet; det gælder både selvbiografien og følgebrevet. Rettelserne skal siden omtales lidt 
134

Jens Peter Agidius

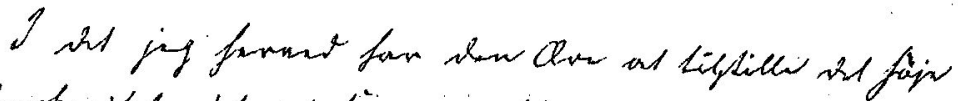

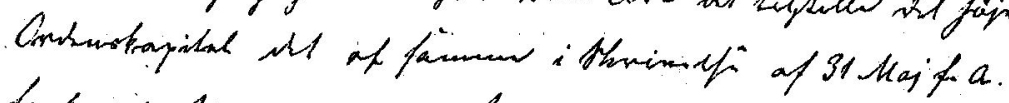

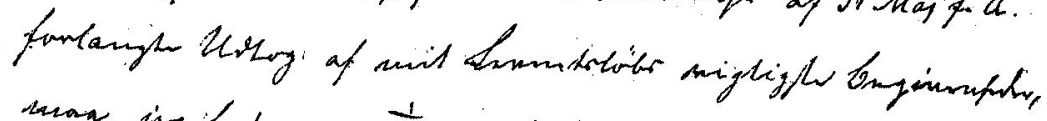

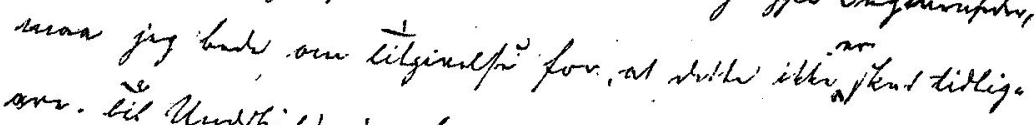

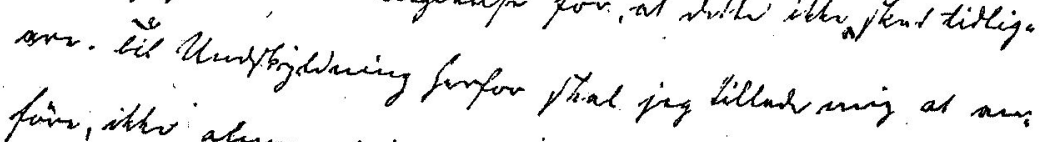

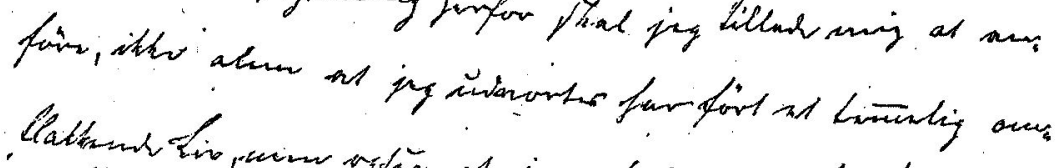

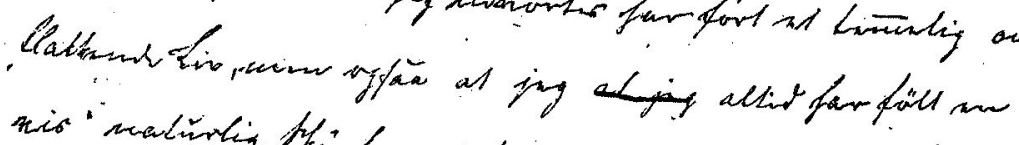

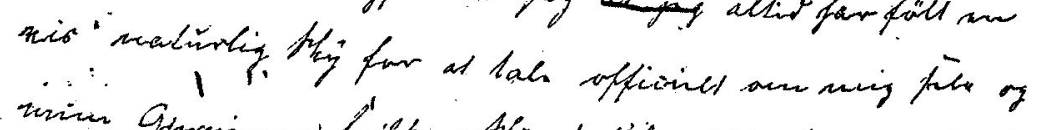

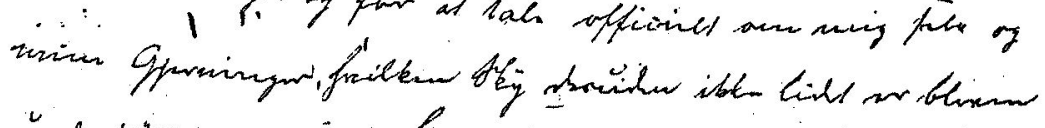

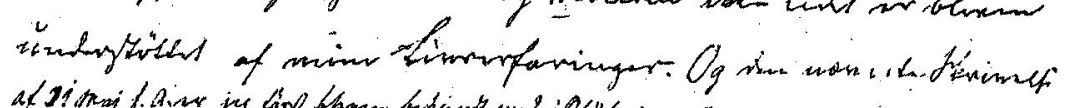

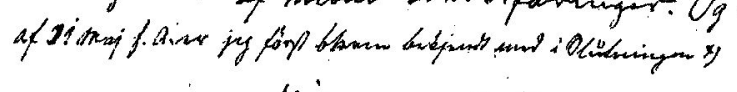

Livosman 23 Yamier $186 \%$.

arbinkifl

Qurrition Flor.

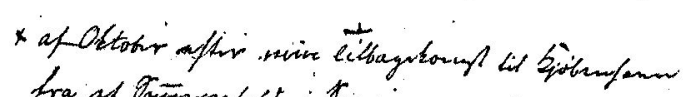
fraint samenosfoct i tarig.

ail

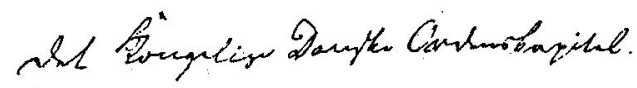

Den 23.januar 1867 sendte Christian Flor sin levnedsberetning til Ordenskapitlet. Beretningen blev ledsaget af et folgebrev - her gengivet efter Flors egenhandige kladde. Det kongelige Bibliotek.

nærmere. Efter at have foretaget disse rettelser må Flor have ladet det foreliggende manuskript afskrive, formodentlig igen ved Koch, og selv har han da vel skrevet et nyt følgebrev, og fået det sendt til Ordenskapitlet. Dér er det $\mathrm{i}$ 
hvert fald $\mathrm{i}$ en protokol noteret modtaget $\mathrm{i}$ året 1867. Når dette nye manuskript imidlertid ikke findes dér, skyldes det, at det sammen med alle de andre ordensmedlemmers selvbiografier blev flammernes bytte ved Christiansborgs brand den 3.oktober 1884. Derimod fik de soldater, der blev sat ind mod branden, reddet den protokol, hvori modtagelsen af Flors selvbiografi er noteret.

Selvbiografien er første gang benyttet allerede i Berlingske Tidendes nekrolog over Flor den 2. april $1875,{ }^{3}$ med henvisning til »en Kilde, der er bleven os velvillig overladt, nemlig en af Flor selv i Aaret 1867 nedskreven kort Biographi«. Om det har været det foreliggende manuskript A eller det nu ikke mere eksisterende manuskript $\mathrm{B}$, udlånt af Ordenskapitlet, kan ikke afgøres med sikkerhed. Fra det tidspunkt har det været kendt, og er siden blevet læst, brugt og citeret af historikere og andre, i størst udstrækning af Th. Roust i hans Flor-biografi fra $1923 .{ }^{4}$ Men trykt $i$ sin helhed er den altså ikke blevet før nu i 200-året for Flors fødsel.

Hvad de rettelser angår, som Flor har foretaget i det af Koch nedskrevne, da falder de i flere kategorier: dels tilretning hen imod en mere "moderne" retskrivning; Flor fulgte det såkaldte Rask'ske reformforslag fra sprogforskeren Rasmus Kr. Rasks skrift fra 1826 om »en videnskabelig retskrivning«; fuld konsekvens har han dog ikke opnået her. Dels om små ændringer og tilføjelser i ordvalget og forbedringer i sætningsstillingen, om korrigering af årstal, hvor Flor i første omgang har været usikker og så har slået efter $i$ egne notater eller andetsteds. Endelig er der en enkelt ændring i afsnitsinddelingen, så der nu er $i$ alt tretten afsnit. Alle rettelserne under ét er at betragte som finjusteringer, der således vidner om, hvor omhyggelig Flor var for at udtrykke sig så korrekt, nøjagtigt og klart som muligt.

Som rettesnor for omfanget og udvælgelsen af hvad der skulle tages med, og hvad der skulle udelades, ser det ikke ud til, at der fra opgavestillerens Ordenskapitlets - side er givet andet end formuleringen: "Deres Levnetsløbs vigtigste Begivenheder . Forsøger man at overskue disponeringen i storafsnit uden hensyn i øvrigt til de anbragte linjeskift, kommer man til følgende femdeling: 1) afsnit 1 om Flors fødselsår og -dag, og om forældrene, især faderen; 2) afsnittene 2-6 om skolegang, studietid, tiden som ung lærer og siden som præst, frem til ansættelsen i Kiel, altsammen at opfatte som en forberedelse til det følgende; 3) afsnittene 7-10 om begyndelsen i Kiel og den gradvise erkendelse og formulering af den egentlige livsopgave, hvorfra alle hans bestræbelser siden udgik; 4) afsnittene 11-12 om den oppositionelle stilling han derved kom til at indtage frem til 1848, om de venner som stod ved hans side i den kamp, livsopgaven forte med sig, samt om de "våben«, han fik 
smedet sig til denne kamp; og endelig 5) afsnit 13 om hans ydre stilling dels privat, dels offentligt, herunder afskeden fra universitetet i Kiel i $1845 \mathrm{og}$ hans opholdssteder derefter, og til allersidst de offentlige tillidshverv og officielle udmærkelser, som tilfaldt ham, efter at hans egentlige, aktive livsværk var afsluttet i 1848. Af disse fem storafsnit forekommer det tredje, midterste at være også indholdsmæssigt det centrale og det fyldigste, dog er også det foregående, især i skildringen af overgangene fra en fase til den næste, af en vis fylde. Det synes, som om Flor har tænkt, at alt, hvad der fulgte derefter, det jeg har kaldt det »egentlige, aktive livsværk«, jo i forvejen var offentligt kendt, og at interessen derfor måtte samles om, hvad han selv havde dertil at føje: forberedelsen og vejen frem dertil.

Er der noget, Flors stil i denne selvbiografi ikke er, så er det lyrisk malende; det beskrivende fremstillingselement indskrænker sig til korte, beherskede karakteristikker, så at sige i forbigående, af nogle få personer, som hver til sin tid fik afgørende indflydelse på hans levnedsgang: rektor Michael Nielsen på Borgerdydsskolen, etatsråd Zeuthen på Tølløsegård, dennes datter, som blev Flors hustru, konferensråd Høpp i det »tyske kancelli« og kong Frederik den Sjette. Ellers er det det episke element, som er helt overvejende, og stilen kan vel ligefrem betegnes som tør, kortfattet, koncis og informationsladet. Levende bliver fortællingen alligevel gennem de samtaler, som formidler de omtalte overgange. Ydermere munder de mest afgørende af disse samtaler ud i ordret anførte replikker: den samtale med etatsråd Zeuthen, som fører til Flors kaldelse til sognepræst i Tølløse, og den anden samtale med kong Frederik den Sjette, som fører til hans erkendelse af, at ovenfra, gennem konge og regering, lod hans livs opgave sig ikke udføre. De øvrige samtaler, og det er ikke så få, gemmer sig i kortere eller længere referat.

Disse hovedtræk i selvbiografiens fortællestil erindrer om den klassiske islandske sagas stil. Bevidst eller ubevidst har Flor ladet sin stil farve af de sagaer, han selv satte højt, og som han var en af de første, om ikke den første, til at indføre som undervisningsstof: $i$ sin egen universitetsundervisning, og siden i dansk skoleundervisning, gennem sin "Haandbog«. Indlysende er jo de forskelle fra sagaen, som ligger $i$, at her er tale om en selvbiografisk beretning fra en anden, og anderledes, tid end sagaernes, foruden deri at Flor er så tilbageholdende med at bringe sin egen person, som dog er "sagaens helt«, frem i rampelyset. Denne tilbageholdenhed var et fast og gennemgående karaktertræk, som han også selv erkendte og bl.a. brugte som undskyldning for sin meget forsinkede og halvvejs modstræbende besvarelse af Ordenskapitlets opfordring. Ikke lyst eller stærk trang til at fortælle om sig selv og sine egne gerninger er drivkraften bag beretningen, men pligtfølelse. Men når han så fortæller, gør han det velovervejet og afrundet, og med omhu for, at det skal 
fremgå klart, at hvad der $\mathrm{i}$ hans livs forløb er tilfaldet ham af begunstigelser, er ikke noget, han uretmæssigt har skaffet sig selv, men skæbne, så at sige, eller lykkeligt, uventet tilfælde. Karakteristisk for hans omtale af personer er, at han altid giver dem fuldt ud den ære, der tilkommer dem, - blot med én undtagelse: hans "hovedfjende«, historiens skurk, så at sige: konferensråd Høpp, der må nøjes med en negativ karakteristik.

Når det er sagt, at Flors stil i hovedsagen nærmest er tør, behersket, først og fremmest informerende om faktiske forhold, så må det dog tilføjes, at enkelte steder ulmer det under den af en lidenskab, som får ham til at ty til ord og vendinger fra den religiøse sfære: hvor han $\mathrm{i}$ forbindelse med sin erkendte livsopgave skriver om sin bestræbelse på at erfare »hvad Befolkningen, Bønderne og Borgerne [i Sønderjylland] selv følte ved Forkuelsen og Forhaanelsen af deres Modersmaal« (afsnit 8), og lidt senere, da han vender tilbage til »det gamle Modersmaal, som Skaberen havde anvist dem til aandelig Arv og Eie«, og sit arbejde for at vække denne befolknings syn for, »at det var deres stolte Ret og deres hellige Pligt at bevare og forsvare dette som deres bedste menneskelige Eiendom." (afsnit 10). Disse passager er helt centrale udtryk for Flors opfattelse af sit anliggendes art.

Dette, at han, som antydet, har lagt sin skæbne $\mathrm{i}$ højere magters hånd og omhyggeligt har afholdt sig fra at tage selv, afspejler sig f.eks. deri, at hans skildring af ungdomstiden tager karakter af et klassisk folkeeventyr: jeg tænker på, hvordan han, som det her fortælles, $i$ en ung alder, uden forbindelser, men besjælet af pligtfølelse og ærlig vilje til at opfylde, hvad ret er, kom »til ære og værdighed« som sognepræst i et anseligt embede - noget på den tid temmelig usædvanligt- og oven $\mathrm{i}$ købet så også vandt sig "prinsessen og det halve kongerige « $i$ skikkelse af den rige gods- og kirkeejers eneste datter og med hende også hendes arv, men ikke uden først at måtte igennem en krævende prøve, i hans tilfælde: at skrive en afhandling på latin og derved erhverve doktortitelen. Dette »eventyr « slutter med den yderst kortfattede omtale af giftermålet, og dermed er ungdommen som forberedelsestid forbi. De næstfølgende afsnit omhandler hans gradvise erkendelse af livsopgaven og dens vilkår - i grunden en ligeledes klassisk fortsættelse dér, hvor eventyret traditionelt slutter - og tager vi afsnit 12 med om arbejdet på at løse livsopgaven, så er dermed manddomstiden omskrevet. I disse to hovedafsnit er det, vi finder den levende vekslen mellem episk fortælling og dramatisk tilspidsning. Afsnit 13 derimod, om alderdomstiden, indskrænker sig til ren, tør information.

Blandt de adskillige anførte årstal er der ét, som får en særlig fremhævning, derved nemlig, at det står alene i sin sammenhæng: året 1844 for oprettelsen af Rødding Folkehøjskole. Det nævnes som det sidste, men ingenlunde mindste, tværtimod, af hans tiltag eller resultater $i$ arbejdet wfor at vække aandeligt 
Liv og Bevidsthed hos den danske Befolkning i Sønderjylland « - gennem "Oplysning«: fremhæuningen viser, hvor vigtigt netop dette ord er for ham.

Hvad der kan virke påfaldende ved denne skildring af et langt liv er ved første øjekast - dens korthed. Derfor har det interesse at vurdere den udvælgelse, Flor her har foretaget: hvad han har taget med og hvad han har udeladt. En forklaring på kortheden er allerede antydet $\mathrm{i}$ hans uvilje mod at fortælle om sig selv og sine egne gerninger, og en retningslinje for udvalgelsen er givet i opfordringen til at meddele en optegnelse af hans livs "vigtigste Begivenheder«. Det har han på egen hånd fortolkende begrænset til: de vigtigste ydre begivenheder. Selvbiografien står da som udtryk for, hvad den 75-årige Flor ved et tilbageblik på sit lange liv opfattede som dets vigtigste begivenheder set med det ydre øje, og yderligere begrænset af den tanke, at af hans kendte offentlige virke havde det ikke interesse at gentage uden de nøgne hovedpunkter. Var han udtrykkeligt blevet opfordret til at berette også om sit livs indre begivenheder, havde han næppe undladt at omtale sit møde som purungt menneske med Oehlenschlægers ungdomsdigtning og den livslangt virkende vækkelse ved »Nordens ånd", som han erfarede gennem den; ejheller havde han da undladt at fortælle om sit møde i moden alder med Grundtvig og hans idéverden, og hans på én gang helhjertede og velovervejede overgivelse til den. Men en diskretion og sans for det passende: en medbragt arv fra det attende århundrede og måske også fra aristokratisk omgang i de unge år har fået ham til at forbeholde betroelser om disse forhold til sine mere fortrolige venner. Hvad han har givet $\mathrm{i}$ den foreliggende selvbiografi er da, ud over de nøgne data iklædt kun den nødtørftigste fortælling: en forholdsvis fyldig, enkelte steder i samtalesituationer udfoldet redegørelse for de skæbnens underlige veje og omveje, som omsider forte ham til Kiel og til hans livs opgave, for hans overvejelser derved, Skæbnens eller Forsynets forberedelse af ham til at løse denne opgave, og ligeledes de oplevelser, erfaringer og ræsonnementer, som ledte ham frem til erkendelsen af, ad hvilke veje den måtte udføres.

Det synes rimeligt at betragte Flors korte beretning som en myte. Sådan skaber ethvert levende og vågent menneske sig erindrende sin egen myte. I og med at Flor var, eller blev, en mand, som ikke blot tjente sig selv og sin egen sag, men folkets, er hans myte da også en folkelig myte. Mellem myter og såkaldt historisk sandhed er der et dialektisk forhold: myten forlener de givne historiske data med menneskelig form og levende liv, men må til gengæld selv være underkastet stadig korrektion fra fakta. Ud fra dette synspunkt er vist nok det interessanteste og også mest omstridte punkt $i$ den her forelagte selvbiografi Flors påstand: at han allerede fra sin allerførste tid i Kiel, ved juletid 1826, var klar over, at der konspireredes slesvig-holstensk ved universitetet dér, og en dermed sammenhængende påstand om, at han så tidligt som 


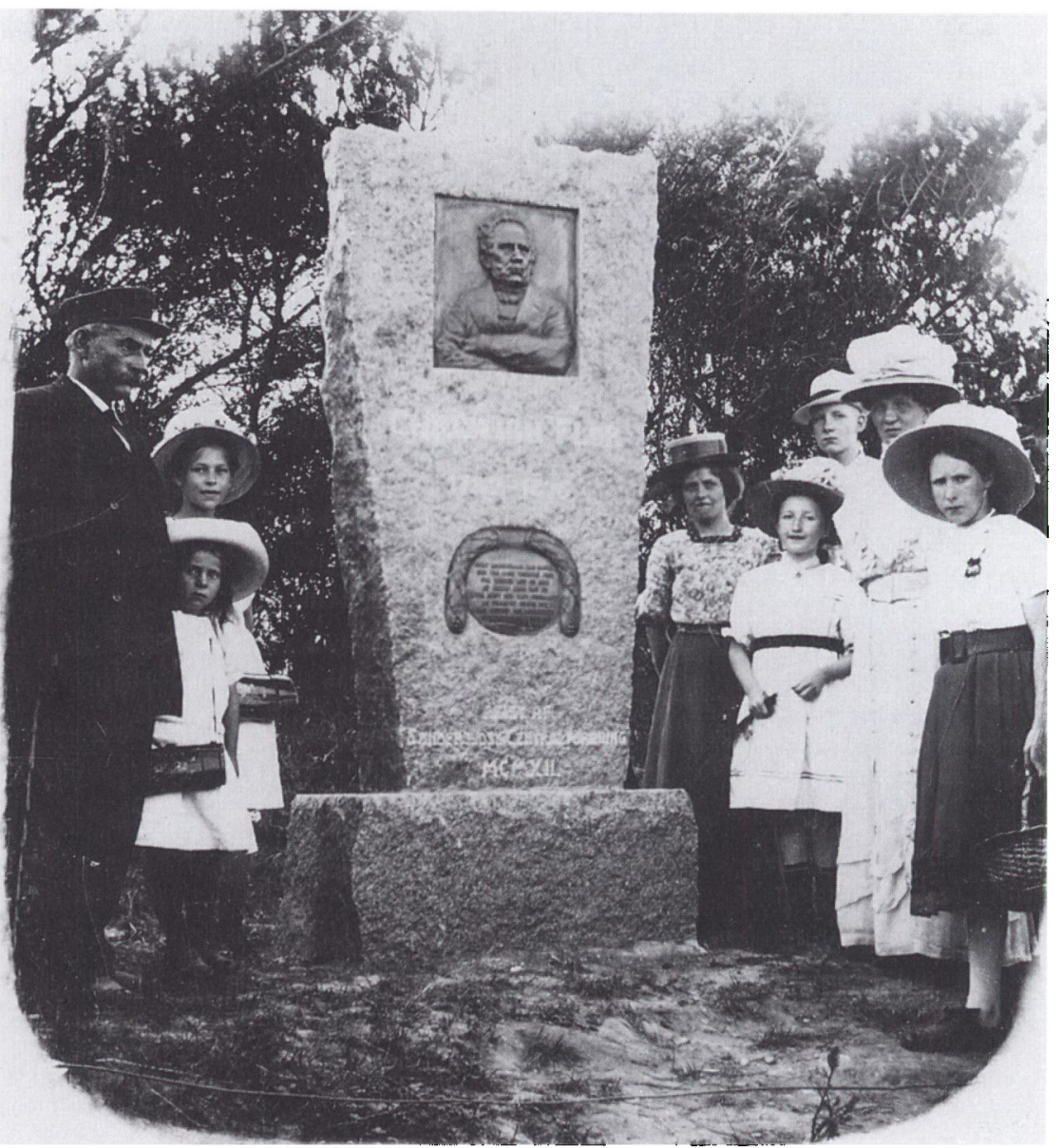

Den 14.juli 1912 deltog en forsamling på omkring 2000 mennesker i afsloringen af dette mindesmarke for Christian Flor på Skamlingsbanke. Sonderjydsk Centralforening havde taget initiativet, og foreningen havde samtidig sarget for vedligeholdelse af Flors grav pd Garnisons kirkegdrd $i$ Kobenhavn. Under portratrelieffet barer mindestenen et bronzeskjold med vers af C. Ploug:

Vort Modersmaal han elsked,

hun var hans Ungdomsbrud.

For hendes Ret og AEre

at varge drog han ud.

Hvor mest hun blev forhaanet

og tramped under Fod

han hendes Ros forkyndte

med frit og frejdigt Mod.

Postkort 1912 i Det kongelige Bibliotek. 
i 1827, og endnu en gang i 1828, fulgte dette op i en audiens hos kongen, men da måtte erkende, at der ikke lod sig noget gøre for folket i Sønderjylland ad den vej. Dette har man ment at måtte betragte som erindringsforskydning, og villet henlægge den sidste, udslaggivende audiens i stedet til 1832, da Flor var sammen med sin kollega Chr. Paulsen i København. ${ }^{6}$ En læser af manuskriptet har ikke kunnet dy sig for at anbringe et blyantskrevet spørgsmålstegn i marginen ud for denne passage $i$ beretningen. Begrundelsen for ikke at ville fæste tiltro til Flors egen erindring er da den, at han jo ikke fulgte sin påståede klare erkendelse op i ydre handling før et godt stykke hen i 1830'rne. Der kan nu argumenteres både for og imod, men den diskussion hører ikke hjemme her, hvor det blot er meningen at bringe et aktstykke, der længe har ligget halvt upåagtet, ud til offentligheden i dets helhed. Det er da hermed gjort.

\section{NOTER}

1. Ifølge Lorenz Rerup i Dansk Biografisk Leksikon, bd. 8 (1981) side 131.

2. Skriften her i manuskriptet er adskilligt stejlere end skriften i brevene til og med 1855, men synes ellers umiddelbart at stemme godt med Kochs karakter.

3. Flor døde den 31.marts 1875.

4. Th. Roust, Christian Flor. Træk af et Levnedsløb og af Danskhedens Gennembrud i Sønderjylland (Flensborg, 1923).

5. Man skelner i de fleste tilfælde let imellem Kochs rettelser af fejlskrift under dikteringen, og Flors rettelser foretaget da han efter nedskriften har sat sig hen for at gennemse det skrevne.

6. Knud Fabricius i Senderjyllands Historie fremstillet for det danske Folk, bind 4 (Kbh., 193739) side 215. Desuden er selvbiografien kritisk omtalt i Johann Runge: Christian Paulsens politische Entwicklung. Quellen und Forschungen zur Geschichte Schleswig-Holsteins bd. 57, 1969 side 102. 